\title{
POLA PERMUKIMAN MULTIETNIK DI KAMPUNG ISLAM KEPAON KOTA DENPASAR DAN KAWASAN KAMPUNG MELAYU DI KOTA SEMARANG
}

\author{
Endy Agustian, Rini Rachmawati, R Rijanta dan Agus Joko Pitoyo \\ Universitas Gadjah Mada Yogyakarta, Indonesia \\ Email: endyagustian@gmail.com, rinirachma@ugm.ac.id, rijanta@ugm.ac.id dan \\ aguspit@ugm.ac.id
}

\section{Abstract}

This research aims to identify the pattern of multiethnic settlements both in Kampung Islam Kepaon Denpasar and in the Kampung Melayu Area of Semarang City. The research method used in this study is qualitative method of case study with the number of research cases consisting of two cases (plural/double), namely Kampung Islam Kepon in Denpasar City and Kampung Melayu Area in Semarang City. This research was conducted by exploring phenomena related to settlement patterns in each research case study. The results showed that the pattern of multiethnic settlements in Kampung Islam Kepaon Denpasar city and Kampung Melayu Area semarang city both form a pattern of settlement colonization / grouping with a shape resembling a rectangle and follow the pattern of roads in the settlement and the direction of the river. The formation of settlement patterns in each case study can be accommodated due to historical factors and also the strength of the kinship system.

Keywords: patterns; settlements; multiethnic; diversity; Denpasar; Semarang

\begin{abstract}
Abstrak
Penelitian ini bertujuan untuk mengidentifikasi pola permukiman multietnik baik yang terdapat di Kampung Islam Kepaon Kota Denpasar maupun di Kawasan Kampung Melayu Kota Semarang. Metode penelitian yang digunakan di dalam penelitian ini ialah metode kualitatif studi kasus dengan jumlah kasus penelitian yang terdiri atas dua kasus (jamak/ganda), yaitu Kampung Islam Kepon di Kota Denpasar dan Kawasan Kampung Melayu di Kota Semarang. Penelitian ini dilakukan dengan cara mengeksplorasi fenomena yang berkaitan dengan pola permukiman pada masing-masing studi kasus penelitian. Hasil penelitian menunjukkan bahwa pola permukiman multietnik di Kampung Islam Kepaon Kota Denpasar dan Kawasan Kampung Melayu Kota Semarang keduanya membentuk pola permukiman kolonisasi/mengelompok dengan bentuk menyerupai persegi Panjang dan mengikuti pola jalan di dalam permukiman dan arah sungai. Terbentuknya pola permukiman pada masing-masing studi kasus dapat disimpulkan karena adanya faktor sejarah dan juga kuatnya sistem kekerabatan.
\end{abstract}

Kata kunci: pola; permukiman; multietnik; kemajemukan; Denpasar; Semarang

$\begin{array}{ll}\text { How to cite: } & \text { Agustian, Endy. Et. al (2021) Pola Permukiman Multietnik Di Kampung Islam Kepaon Kota Denpasar } \\ & \text { Dan Kawasan Kampung Melayu di Kota Semarang. Syntax Literate: Jurnal Ilmiah Indonesia 6(4). } \\ & \text { http:// 10.36418/syntax-literate.v6i4.2467 } \\ & \text { 2548-1398 } \\ \text { E-ISSN: } & \text { Ridwan Institute }\end{array}$




\section{Pendahuluan}

Indonesia merupakan contoh negara dengan keanekaragaman yang besar di dunia. Hal tersebut dapat dilihat dari kemajemukan bangsanya yang terdiri atas berbagai kewarganegaraan, suku, adat istiadat, kebudayaan, agama, dan bahasa (Na'im, A., \& Syaputra, 2010). Kemajemukan tersebut dapat dilihat pada tatanan kehidupan masyarakatnya yang hidup secara berdampingan maupun bersama-sama baik secara fisik maupun non fisik.

Penelitian ini merupakan kajian yang berkaitan dengan permukiman multietnik di Indonesia. Pada dasarnya, permukiman merupakan bagian dari ruang dan waktu berupa wadah ataupun tempat hunian dalam bentuk perumahan yang dimanfaatkan oleh manusia untuk menyelenggarakan kehidupan (Kardono, 2015); (Wesnawa, 2015). Adanya permukiman multietnik dapat diidentifikasi berdasarkan pada golongan manusia atas dasar garis keturunan ataupun latar belakang pada agama atau kepercayaan, nilai-nilai dasar kehidupan, kebiasaan, adat istiadat, norma, bahasa, sejarah, kondisi geografis, dan hubungan kekerabatan. Selain itu, adanya benang merah yang jelas antara peristiwa yang telah terjadi pada masa lalu dan masa kini menjadikan masyarakat tersebut menetap secara berkoloni/berkumpul sesuai dengan golongan tersendiri.

Terbentuknya suatu permukiman multietnik pada suatu wilayah merupakan bagian dari warisan budaya bagi kelompok/komunitas etnik yang memutuskan untuk bermukim disuatu tempat tertentu (Maguire, J., Grant., Louise, M., \& Joe, 2002). Oleh sebab itu, maka dapat ditegaskan bahwa permukiman multietnik merupakan suatu permukiman yang dihuni oleh masyarakat dengan latar belakang yang berbeda-beda. Di sisi lainnya, suatu permukiman dapat membentuk suatu pola yang merupakan cara manusia dalam menempatkan dirinya di atas lanskap yang mengacu pada tempat tinggal, pengaturan masyarakat, sifat dan disposisi bangunan-bangunan yang berkaitan dengan kehidupan masyarakat (Thomas, J., \& David, 2016). Pola permukiman dapat terbentuk karena adanya ketidaksetaraan sosial, interelasi berkelanjutan dari kelompok yang berada diberbagai daerah, serta interaksi antar manusia dan ruang yang diatur di dalam struktur ruang. Di sisi lainnya, struktur ruang memengaruhi tindakan dan perilaku manusia yang akan memperkuat, menyesuaikan atau mengubah pola ruang permukiman yang mereka buat dan gunakan (Markovich, N. C., Preiser, W., \& Strum, 2015).

Berbagai macam kajian mengenai permukiman multietnik telah banyak dilakukan baik di Indonesia maupun di dunia (di luar Indonesia) dengan sudut pandangan dan permasalahan yang berbeda-beda. Adapun hasil dari kajian tersebut menunjukkan bahwa permasalahan yang berhubungan dengan permukiman multietnik sangat bervariasi, seperti: faktor pembentuk permukiman etnik yang disebabkan karena faktor migrasi (Zhang, Druijven, \& Strijker, 2019); Adanya proses indigenisasi multietnik dan multireligi sebagai faktor pembentuk permukiman multietnik (Maximova \& Belyaev, 2017), karakteristik permukiman multietnik di tepian sungai yang diihat berdasarkan pada aspek fisik, aspek ekonomi, dan aspek sosial-bidaya (Agustian, Rachmawati, Rijanta, \& Pitoyo, 2020), arsitektur permukiman masyarakat etnik yang dipengaruhi 
oleh keterlekatan sosial (Woy, Siahaan, \& Tobing, 2018); Arsitektur, ruang, dan sejarah permukiman etnik sebagai kekuatan otoritas untuk mengendalikan wilayah (Ariestadi \& Wulandari, 2017); Pola struktur arsitektur Melayu (Zain, 2017), konsep kebertahanan masyarakat etnik berdasarkan pada nilai-nilai Islam (Agustian, Rachmawati, Rijanta, \& Pitoyo, 2020); Konsep kebertahanan masyartakat etnik berdasarkan pada modal sosial (keluarga, etnik, agama) (Chai, Ueland, \& Phiri, 2018); Identitas lokas sebagai kebertahanan masyarakat etnik (Streletsky, 2017); (Ariestadi \& Wulandari, 2017); Konsep permukiman berbasis pada nilai-nilai Islam sebagai wujud kebertahanannya (Agustian, 2017), konsep pembentuk ruang masyarakat etnik (Al-Haroun \& Al-Ajmi, 2018); Konsep ruang masyatakat etnik yang membentuk model permukiman yang mengelompok (Wang, Sigler, Corcoran, \& Liu, 2019); konsep ruang masyatakat etnik membentuk pola prilaku etnik (sempit, tidak stabil, ketidakpedulian) (Konstantinov, 2017). Berdasarkan pada hasil penelitian-penelitian sebelumnya, maka dapat disimpulkan bahwa kajian mengenai permukiman multietnik telah dilakukan baik ditinjau berdasarkan pada aspek fisik permukiman maupun aspek fisik non permukiman. Penelitian-penelitian sebelumnya hanya berfokus pada satu kajian baik dalam cakupan substansi yang dicapai di dalam penelitian maupun cakupan dari segi wilayah penelitian. Atas dasar itu, maka dapat ditegaskan bahwa berdasarkan pada hasil kajian mengenai permukiman multietnik sebelumnya masih belum banyak mempertimbangkan aspek lokasi yang menggunakan beberapa lokasi penelitian sebagai bahan kajian. Dengan demikian, maka celah yang dapat diambil di dalam penelitian ini ialah dari sisi lokasi penelitian yang menggunakan jumlah lokasi penelitian sebanyak dua buah lokasi penelitian yang secara tidak langsung sebagai studi kasus penelitian.

Penelitian ini mengambil dua studi kasus permukiman multietnik di Indonesia. Lokasi penelitian ditentukan berdasarkan pada variasi lokasi yang mempunyai karakteristik dan keunikan wilayah yang berbeda-beda antara satu dengan yang lainnya, yaitu: (1) permukiman Kawasan Kampung Melayu di Kota Semarang dan (2) permukiman Kampung Islam Kepaon di Desa Pemogan, Kota Denpasar. Kampung tersebut merupakan sebuah potret permukiman masyarakat yang berbasis Islam dan nilai-nilai tradisi, adat istiadat, budaya, dan kebiasaan warisan leluhur agama Islam di tengah penduduk Bali yang mayoritas beragama Hindu. Kampung Islam Kepaon merupakan satu-satunya kampung Islam yang berada di pusat Kota Denpasar dan sesuai perkembangannya ditempati oleh orang-orang Islam dari berbagai etnik, seperti: etnik Jawa, etnik Madura, etnik Bugis, dan etnik Palembang yang dapat menjaga eksistensinya sampai dengan saat ini. Sementara itu, Kawasan Kampung Melayu merupakan kawasan yang memperlihatkan perpaduan budaya multietnik antara etnik Arab, etnik Tionghoa, etnik Bugis Banjar dan etnik-etnik lainnya yang berasal dari luar Kota Semarang. Keberagaman etnik di dalam permukiman kawasan Kampung Melayu memberikan pengaruh pada sistem penamaan nama kampung, seperti Kampung Pecikan, Kampung Banjar, Kampung Cerbonan, Kampung Baru dan sebagainya. Berdasarkan pada studi kasus penelitian, maka penelitian ini bertujuan untuk mengidentifikasi pola permukiman multietnik pada masing-masing studi kasus 
penelitian, yaitu (1) permukiman Kawasan Kampung Melayu di Kota Semarang dan (2) permukiman Kampung Islam Kepaon di Desa Pemogan, Kota Denpasar.

\section{Metode Penelitian}

Metode penelitian yang digunakan di dalam penelitian ini ialah metode kualitatif studi kasus. Penelitian ini menggunakan jumlah kasus jamak/ganda (multiple case), dengan jumlah kasus penelitian yang terdiri atas dua kasus penelitian yaitu: (1) permukiman Kawasan Kampung Melayu di Kota Semarang dan (2) permukiman Kampung Islam Kepaon di Desa Pemogan, Kota Denpasar. Dalam metode penelitian studi kasus, terdapat empat aplikasi yang harus diperhatikan, yaitu: (1) menjelaskan hubungan sebab akibat dalam dunia nyata melalui survey atau eksperimen, (2) menggambarkan konteks dan intervensi yang terjadi di dunia nyata, (3) menggambarkan topik-topik tertentu dengan menggunakan deskriptif, dan (4) menjelaskan situasi-situasi yang tidak memiliki satu set hasil yang jelas (Yin, 2014). Data yang digunakan di dalam penelitian ini berdasarkan pada beberapa bukti sumber di dalam metode penelitian studi kasus, meliputi: wawancara (wawancara mendalam), observasi, dokumen, rekaman arsip dan perangkat fisik (Yin, 2014). Pengumpulan data di dalam penelitian ini dilakukan dengan cara mengeksplorasi fenomena yang berkaitan dengan pola permukiman pada masing-masing studi kasus penelitian.

Setelah proses pengumpulan data telah dilakukan, maka data diolah ke dalam spread sheet dan dilakukan pengkodean, tujuannya untuk mempermudah dalam pengorganisasian data. Adapun analisis bukti (data) dalam metode studi kasus terdiri atas pengujian, pengkategorian, pentabulasian, ataupun pengkombinasian bukti-bukti empiri (Yin, 2014). Terdapat lima teknik analisis yang dapat dilakukan dalam melakukan analisis data di dalam metode penelitian studi kasus, yaitu; penjodohan pola, pembuatan penjelasan (eksplanasi), analisis deret waktu, model logika dan sintesis lintas kasus. Masing-masing teknik analisis tersebut dapat diaplikasikan baik pada satu kasus tunggal maupun multikasus dan setiap studi kasus hendaknya mempertimbangkan teknik-teknik tersebut. Penelitian ini juga menggunakan pendekatan keruangan sebagai basis analisis penelitian khususnya untuk menganalisis aspek-aspek keruangan yang digunakan. Di sisi lainnya, penelitian studi kasus terdapat beberapa taktik untuk menentukan kriteria di dalam menentukan kualitas penelitian, yaitu construct validity, internal validity, external validity, reliability (Yin, 2014), serta untuk lebih mendukung kualitas dan verifikasi penelitian maka perlu dilakukan verifikasi yang intensif dengan cara triangulasi dan member check (Stake, 2013).

\section{Hasil dan Pembahasan}

\section{A. Pola Permukiman Multietnik di Kampung Islam Kepaon Kota Denpasar}

Pada dasarnya, terbentuknya suatu permukiman di suatu wilayah merupakan hasil dari kolonisasi dari sekumpulan komunitas yang memutuskan untuk menempati wilayah yang diinginkan, sehingga membentuk suatu dusun/kampung/desa maupun kota. Pola permukiman di Kampung Islam Kepaon 
dapat diketahui melalui dua cara yaitu dengan mengamati citra satelit/foto udara dan juga dengan cara melakukan observasi lapangan secara langsung untuk mengklarifikasi hasil amatan on screen melalui citra satelit/foto udara. Berdasarkan hasil amatan on screen melalui foto udara yang telah terkoreksi, maka dapat dikatakan bahwa pola permukiman di Kampung Islam Kepaon membentuk pola kolonisasi/mengelompok dengan bentuk pola permukiman secara keseluruhan yang menyerupai persegi panjang. Selain itu, penampakan permukiman di Kampung Islam Kepaon dibagi menjadi dua bagian, yaitu permukiman pada bagian timur dan permukiman pada bagian barat dengan pola permukiman yang mengikuti arah jalan dan dipisahkan oleh sebuah sungai yang bernama Sungai Tukad Badung.

Berdasarkan hasil observasi, maka dapat diklarifikasi bahwa pola permukiman yang terdapat di Kampung Islam Kepaon membentuk pola sesuai dengan amatan secara on screen yaitu membentuk pola permukiman kolonisasi/mengelompok.

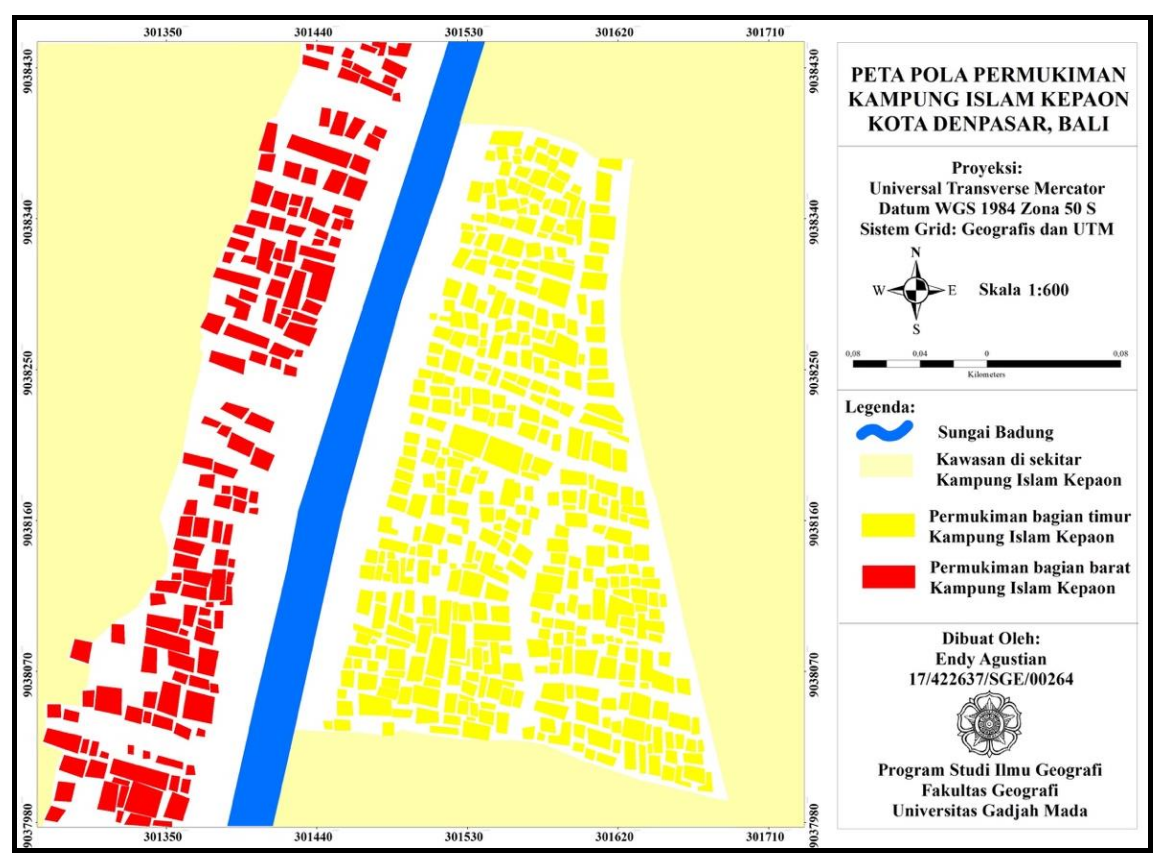

Gambar 1

Pola permukiman di Kampung Islam Kepaon

Berdasarkan sejarahnya, Kampung Islam Kepaon merupakan wilayah yang diberikan oleh Raja Badung Puri Pemecutan kepada para pengawal kerajaan sebagai bentuk penebusan dosanya karena telah membunuh sang anak (Raden Ayu Siti Khadijah). Para pengawal tersebut diberikan sebuah wilayah yaitu wilayah Kepaon untuk melangsungkan kehidupan sampai dengan menghasilkan keturunan. Pada awalnya, Kampung Islam Kepaon dibagi menjadi dua peruntukan lahan, yaitu lahan pertanian dan non pertanian (permukiman). Lahan non pertanian (permukiman) terdapat di bagian timur kampung yang merupakan tempat beraktivitasnya seluruh masyarakat setempat dengan pusat kegiatan, sedangkan pada bagian barat kampung merupakan lahan pertanian berupa sawah maupun kebun nanas dan kelapa. Akan 
tetapi, seiring berjalannya waktu terjadi alih fungsi lahan ataupun pemekaran wilayah yang menjadikan lahan di Kampung Islam Kepaon lebih didominasi oleh lahan non pertanian (permukiman).

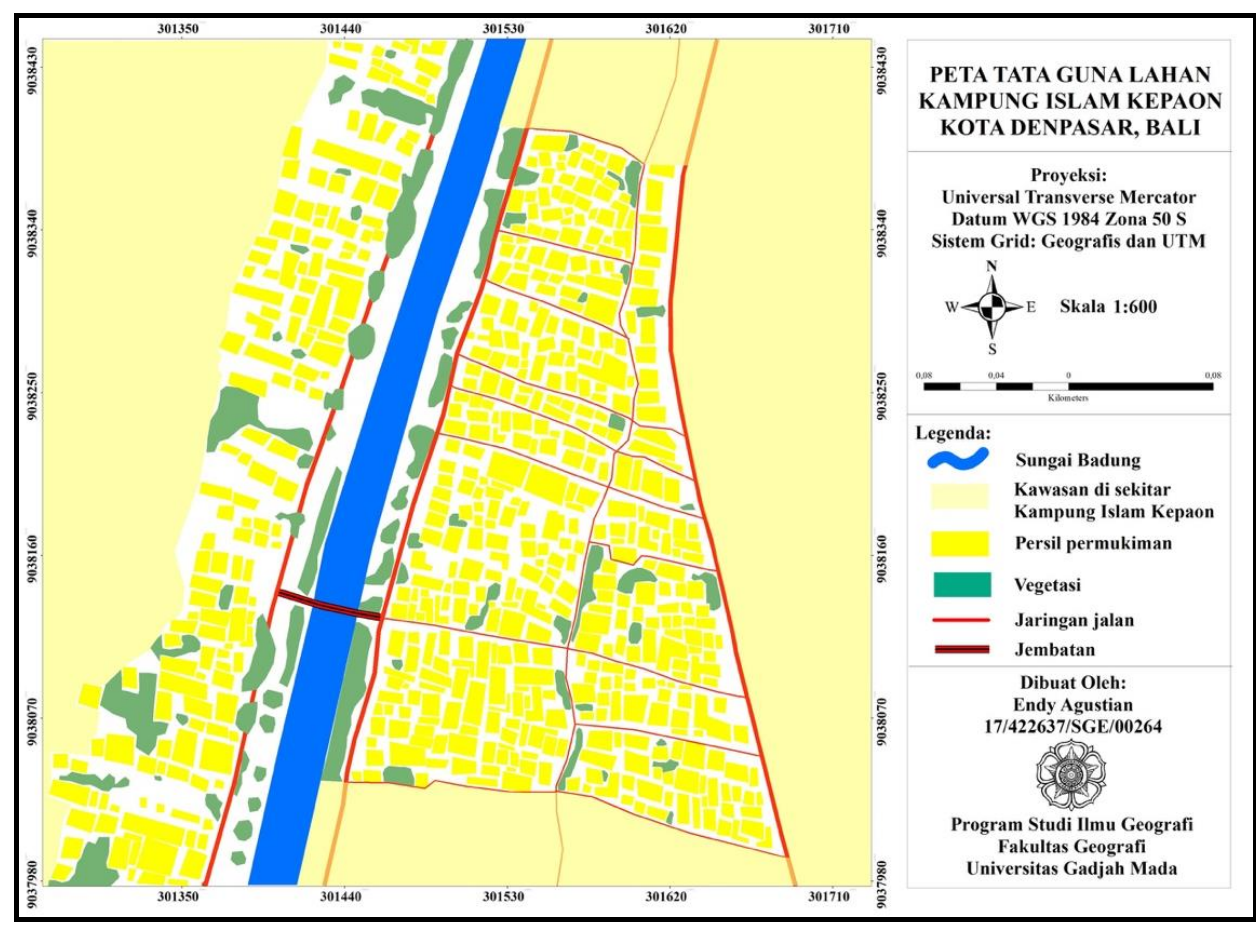

Gambar 2

Tata guna lahan Kampung Islam Kepaon

Pada bagian timur kampung atau berada di sekitar Masjid Besar Al-Muhajirin, permukiman lebih diperuntukan untuk masyarakat lama yang merupakan keturunan dari para pengawal dari Kejaraan Badung Puri Pemecutan, sedangkan, pada bagian barat kampung merupakan permukiman hasil dari alih fungsi lahan yang terjadi pada tahun 1983 dan lebih diperuntukan untuk masyarakat/generasi baru yang berasal dari keturunan-keturunan dari masyarakat pada bagian kampung. Berdasarkan hal tersebut, maka dapat disimpulkan bahwa pola permukiman yang terbentuk di Kampung Islam Kepaon dipengaruhi oleh faktor sejarah dan juga sistem kekerabatan. 


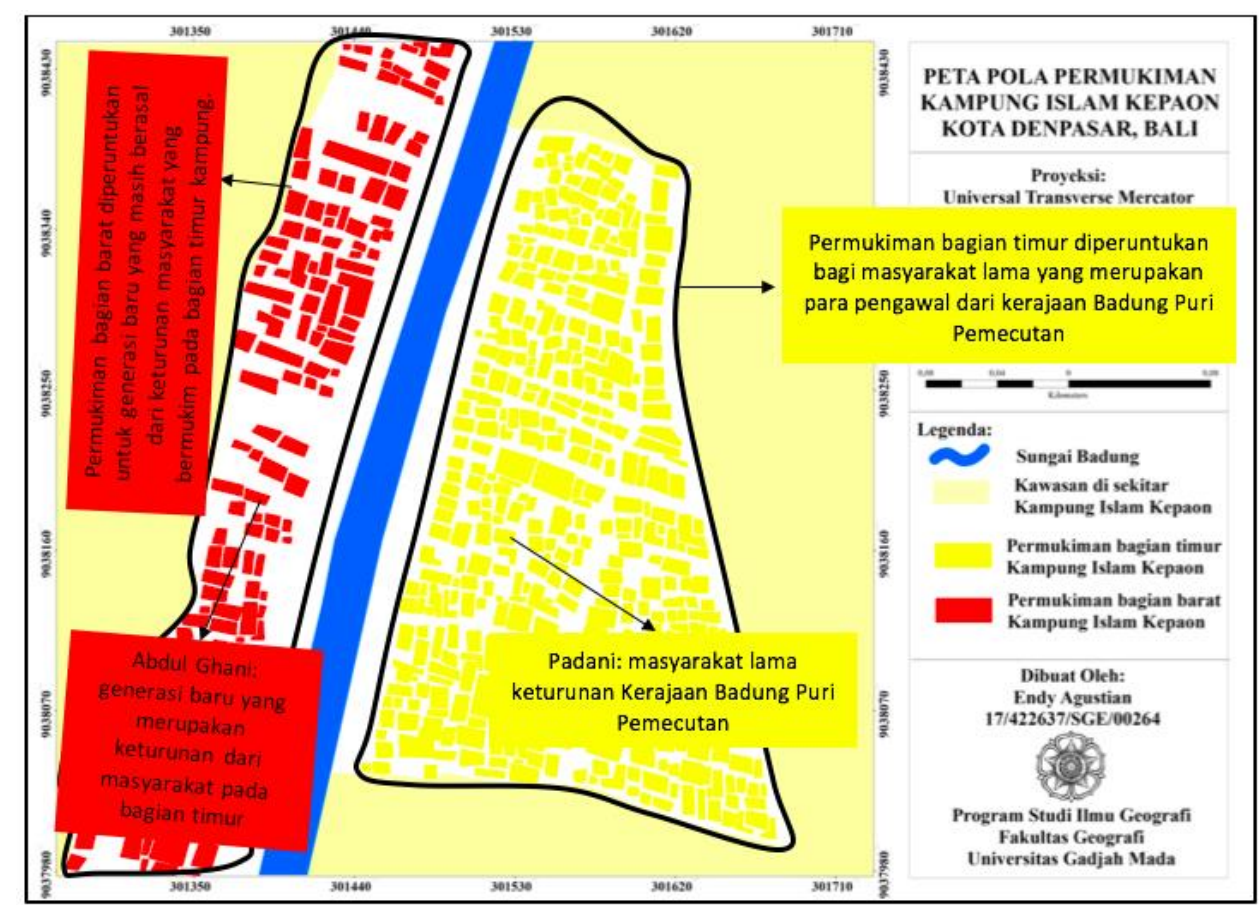

Gambar 3

\section{Pola permukiman di Kampung Islam Kepaon berdasarkan pada pengelompokan kekerabatan}

\section{B. Pola Permukiman Multietnik di Kawasan Kampung Melayu Kota Semarang}

Permukiman dapat dikatakan sebagai suatu kolonisasi dari masyarakat yang tinggal pada suatu wilayah yang sebelumnya telah mengalami proses migrasi. Koloninasi dari masyarakat tersebut membentuk suatu wilayah yang dapat dinamakan sebagai suatu kampung, dusun, desa, maupun kota. Salah satu fenomena permukiman yang telah dieksplorasi pada salah studi kasus penelitian ini ialah permukiman kawasan Kampung Melayu di Kota Semarang.

Pada awalnya, sejak kedatangan para pendatang yang berasal dari Arab, Tiongkok, Banjar, Jawa dan daerah-daerah lainnya dari luar Kota Semarang, permukiman yang terdapat di kawasan Kampung Melayu hanya terkonsentrasi di sepanjang koridor Jalan Layur. Hal ini dikarenakan aktivitas perdagangan yang sangat aktif dan pesat di kawasan tersebut, sehingga menyebabkan para pendatang memutuskan untuk membeli lahan/tanah dan bermukim di kawasan tersebut dengan tujuan untuk mempermudah aktivitas perdagangan mereka. Para pendatang tersebut merupakan para tuan tanah yang mempunyai aset berupa lahan/tanah yang tersebar secara merata di kawasan Kampung Melayu, baik yang sudah didirikan bangunan rumah maupun masih dalam berbentuk lahan kosong. Lahan/tanah tersebut disewakan kepada para pendatang lainnya yang berasal dari berbagai daerah apabila ingin bermukim di kawasan Kampung Melayu.

Seiring berjalannya waktu para pendatang dari berbagai daerah mulai berdatangan ke kawasan Kampung Melayu, sehingga menyebabkan tidak terkonsentrasinya permukiman hanya di sepanjang koridor Jalan Layur saja. 
Permukiman tersebar secara merata di kawasan Kampung Melayu, namun kepadatannya tidak sepadat seperti kondisi saat ini. Selain itu, kawasan Kampung Melayu terdiri atas kampung-kampung yang dihuni oleh banyak pendatang dari berbagai macam etnik dan daerah. Dengan demikian, maka secara tidak langsung memberikan pengaruh terhadap terbentuknya kehidupan yang majemuk di dalam permukiman Kampung Melayu.

Pola permukiman kawasan Kampung Melayu dapat diketahui melalui dua cara yaitu, dengan mengamati citra satelit/foto udara dan juga dengan cara melakukan observasi lapangan secara langsung yang berfungsi sebagai bentuk klarifikasi dari hasil amatan melalui citra satelit/foto udara. Berdasarkan hasil amatan melalui foto udara yang telah terkoreksi dengan cara on screen, maka dapat dikatakan bahwa pola permukiman yang terdapat di kawasan Kampung Melayu membentuk pola permukiman kolonisasi/mengelompok dengan bentuk pola permukiman secara keseluruhan menyerupai persegi panjang. Berdasarkan hasil amatan tersebut, penampakan permukiman di kawasan Kampung Melayu dipenuhi oleh bangunanbangunan yang padat di setiap bloknya dan tidak terdapat lahan/tanah yang tersedia untuk penutup lahan lainnya. Selain itu, blok permukiman yang terdapat pada bagian dalam permukiman membentuk pola yang teratur dan juga mengikuti pola jalan yang terdapat di dalam kawasan tersebut, sedangkan blok permukiman yang terdapat pada bagian timur (sepanjang koridor Jalan Layur) membentuk pola koloniasi/mengelompok yang mengikuti arah Kali Semarang yang terbentang di kawasan Kampung Melayu.

Berdasarkan hasil observasi lapangan, maka telah terklarifikasi bahwa pola permukiman yang terdapat di kawasan Kampung Melayu membentuk pola kolonisasi/mengelompok. Pola permukiman di kawasan Kampung Melayu dipengaruhi oleh faktor sejarah dan sistem kekerabatan yang sangat kental. Perkawinan yang terjadi antar sesama etnik dan perkawinan silang antar etnik memberikan pengaruh terhadap kepadatan di setiap blok permukiman sampai dengan saat ini. Selain itu, kentalnya unsur kekerabatan tersebut juga memberikan pengaruh terhadap tata letak bangunan dengan jarak yang saling berdekatan dan berhadapan antar satu dengan yang lainnya. 


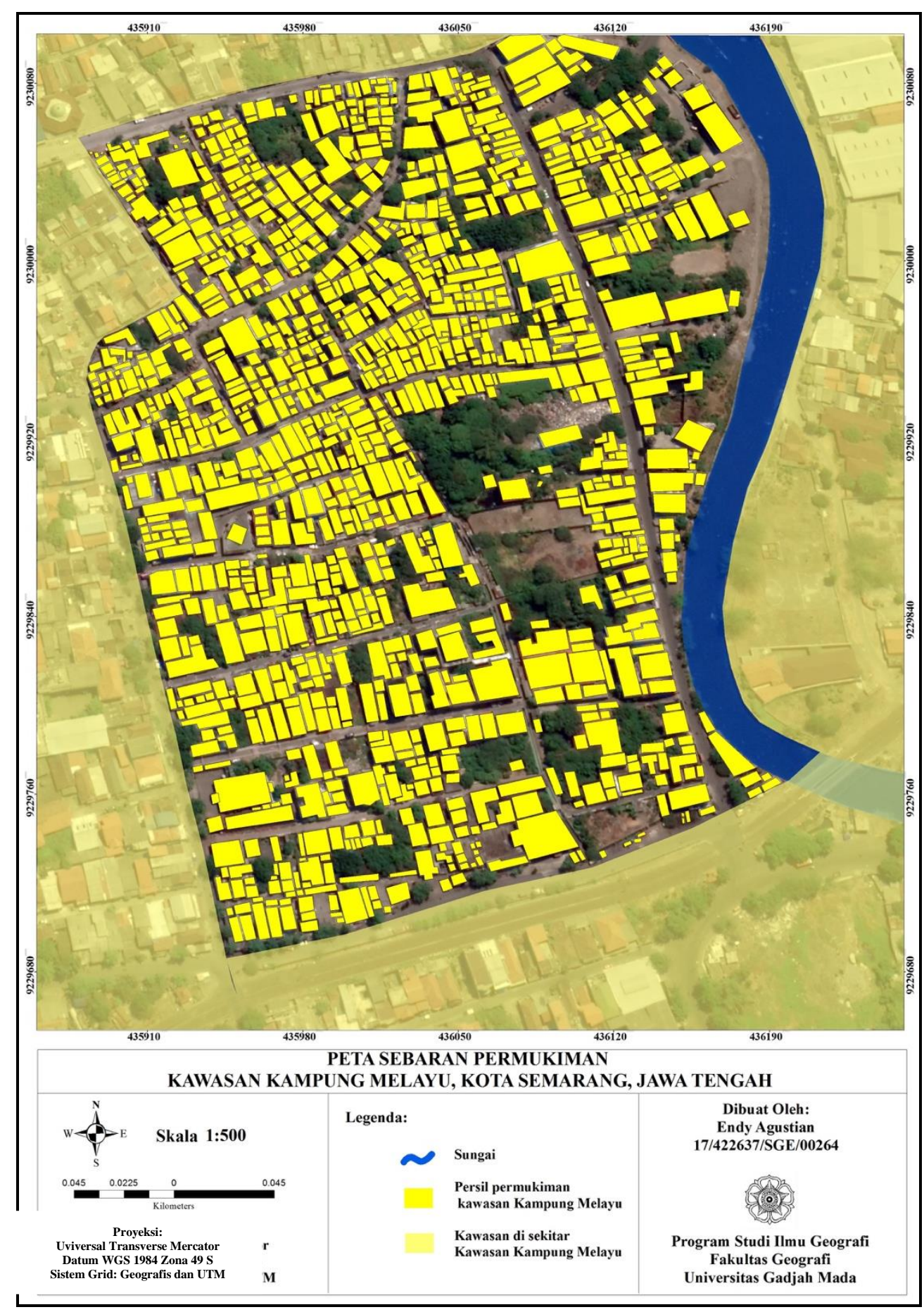

Gambar 4

Pola permukiman di Kawasan Kampung Melayu 


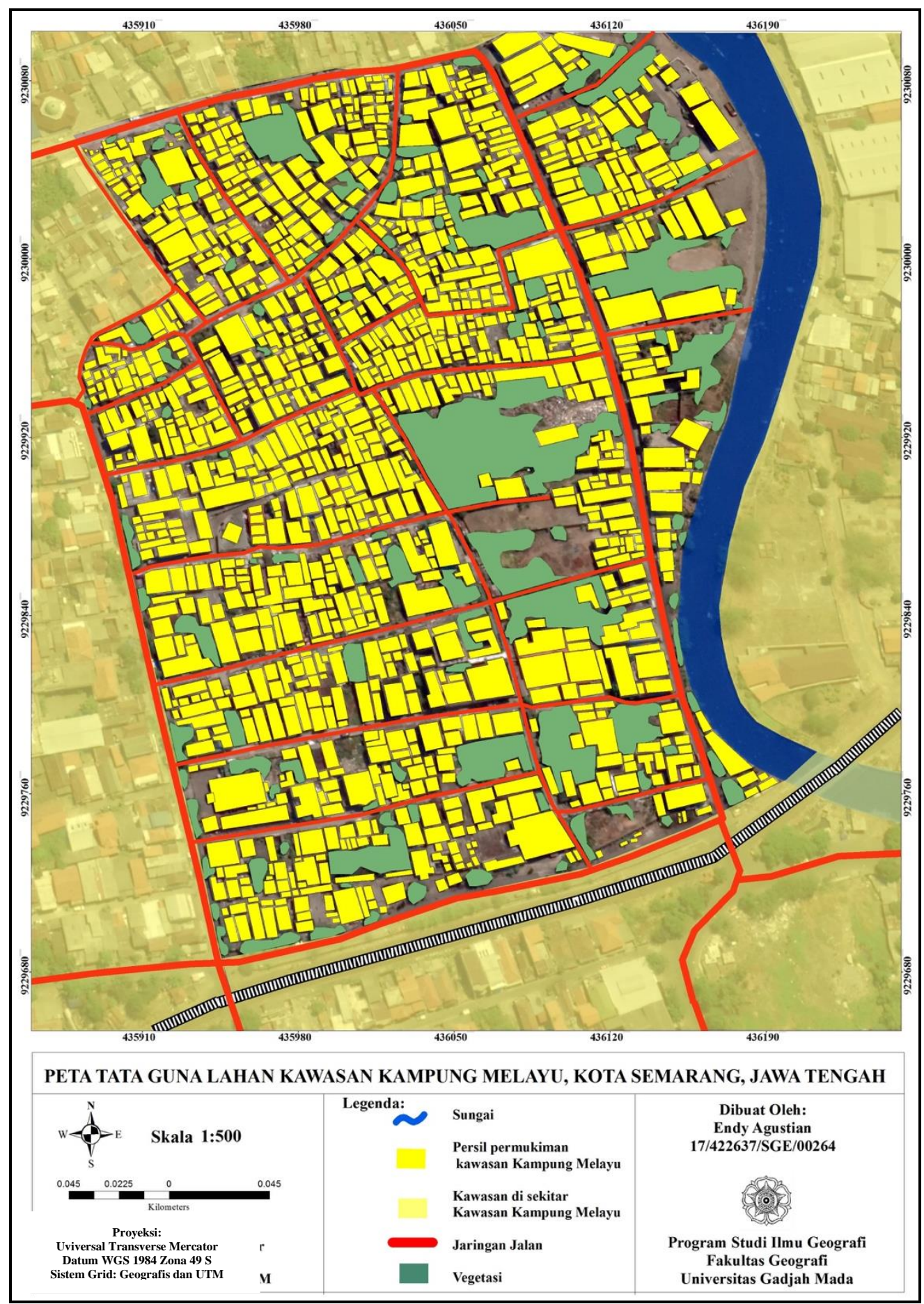

Gambar 5

\section{Tata guna lahan Kawasan Kampung Melayu}

Berdasarkan hasil analisis secara on screen melalui foto udara mengenai tata guna lahan di kawasan Kampung Melayu. Hasil analisis tersebut menunjukkan bahwa tata guna lahan kawasan Kampung Melayu didominasi oleh permukiman dan menunjukkan beberapa penutup lahan lainnya seperti vegetasi berupa pepohonan dan Kali Semarang yang terbentang jelas di kawasan tersebut. Berdasarkan 
sejarahnya, lahan/tanah yang terdapat di kawasan Kampung Melayu sebagian besar berasal dari warisan yang diberikan oleh leluhur terdahulu. Lahan/tanah tersebut kebanyakan dimiliki oleh tuan tanah yang merupakan etnik Arab, etnik Tionghoa, dan etnik Banjar atau generasi pertama yang datang ke kawasan Kampung Melayu. Hal tersebut sejalan dengan kajian yang berkaitan dengan faktor pembentuk permukiman etnik yang disebabkan karena faktor migrasi yang secara tidak langsung sebagai proses terbentuknya suatu kawasan/wilayah yang membetuk suatu komunitas (Zhang, Druijven, \& Strijker, 2019). Berdasarkan hal tersebut, maka dapat dikatakan kesinergian antara fenomena yang ditemukan pada studi kasus penelitian yang dikaitkan dengan hasil penelitian terdahulu.

Pola permukiman kawasan Kampung Melayu membentuk pola permukiman kolonisasi/mengumpul. Pola permukiman tersebut merepresentasikan persebaran etnik atau kelompok etnik yang terdapat pada masing-masing kampung. Di sisi lainnya, pola permukiman kolonisasi/mengumpul mengindikasikan pada pengelompokan dari masing-masing etnik yang bermukim, serta memberikan pengaruh terhadap toponimi kampung (penamaan nama kampung) yang terdapat di kawasan Kampung Melayu. Kawasan Kampung melayu terdiri atas beberapa kampung yang dihuni oleh berbagai macam etnik. Adapun pengelompokan etniketnik yang tersebar di setiap kampung meliputi: (a) etnik Arab: terdapat di Kampung Baru dan Kampung Pencikan; (b) etnik Jawa: terdapat di Kampung Geni Buntu, Kampung Geni Malang, Kampung Geni Besar, Kampung Keranjangan Kecil, Kampung Keranjangan Besar, Kampung Lengkong Kambing, Kampung Boro dan Kampung Lengkong Sop; (c) etnik Madura: terdapat di Kampung Kayu Manis; (d) etnik Banjar: terdapat di Kampung Banjar; (e) etnik Arab Kojo: terdapat di Kampung Peranakan; (f) etnik Arab dan etnik Jawa: terdapat di Kampung Lawang Gajah dan Kampung Geni Kecil; (g) etnik Arab, etnik Jawa, dan etnik Banjar: terdapat di Kampung Kalicilik; (h) etnik Arab, etnik Tionghoa, etnik Banjar, dan etnik Jawa: terdapat di Kampung Pulo dan di sepanjang koridor Jalan Layur; (i) para pendatang dari berbagai daerah di Indonesia: terdapat di Kampung Pace dan Kampung Pelimbungan.

Persebaran etnik di kawasan Kampung Melayu tidak dapat terlepas dari faktor sejarah dan kuatnya sistem kekerabatan di kawasan Kampung Melayu. Adanya perkawinan silang tersebut secara tidak langsung memperkaya kelompok etnik di kawasan Kampung Melayu, serta sebagai cara untuk menciptakan hubungan kekeluargaan/kekerabatan yang sangat erat antar etnik. Kuatnya hubungan kekerabatan antar etnik dapat dilihat pada posisi rumah antar warga atau antar etnik yang saling berdekatan satu dengan lainnya. Adanya persebaran etnik di kawasan Kampung Melayu secara tidak langsung menggambarkan tempat hunian dari masing-masing etnik yang ada. Dengan demikian, maka dapat dinyatakan bahwa persebaran pola hunian dari masing-masing etnik di kawasan Kampung Melayu dapat teridentifikasi dengan baik. Atas dasar itu, maka fenomena yang ditunjukkan di Kawasan Kampung Melayu Kota Semarang dapat memperkaya konsep/teori 
toponimi kampung, kohesi sosial (sistem kekerabatan), permukiman multietnik (pola permukiman multietnik), serta empiri permukiman multietnik yang berkaitan dengan konsep ruang masyarakat etnik (Al-Haroun \& Al-Ajmi, 2018; Wang, Sigler, Corcoran, \& Liu, 2019). Di sisi lainnya, adanya penelitian ini juga memberikan informasi maupun gambaran bagi kasus-kasus permukiman multietnik lainnya khususnya dalam pengembangan penataan pola permukiman multietnik.

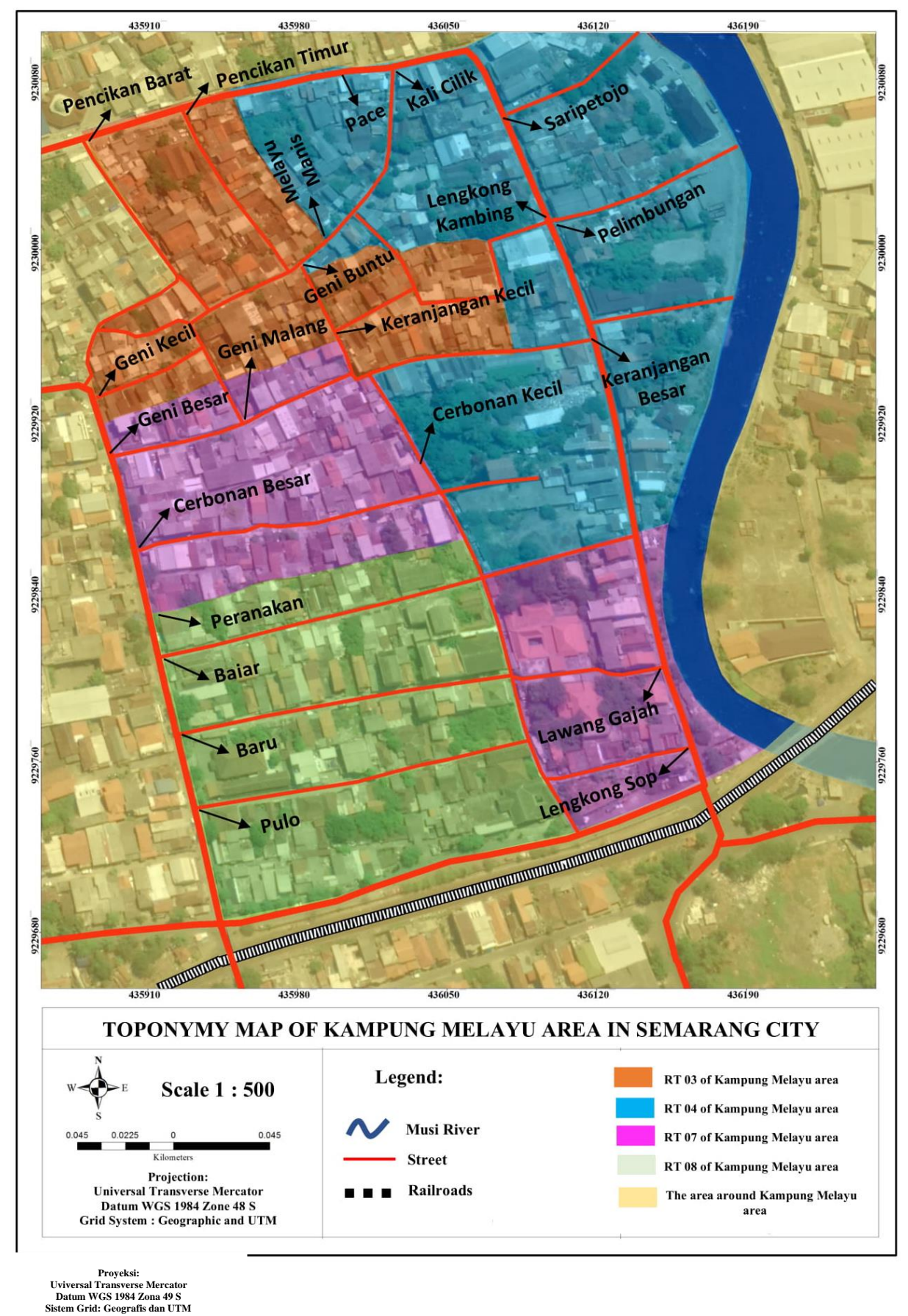

\section{Gambar 6}

Pola permukiman berdasarkan pengelompokan etnik di Kawasan Kampung Melayu 


\section{Kesimpulan}

Pola permukiman multietnik di Kampung Islam Kepaon Kota Denpasar dan Kawasan Kampung Melayu Kota Semarang keduanya membentuk pola permukiman kolonisai/mengelompok. Pola permukiman di Kampung Islam Kepaon Kota Denpasar membentuk pola kolonisasi/mengelompok dengan bentuk pola permukiman secara keseluruhan yang menyerupai persegi panjang. Selain itu, penampakan permukiman di Kampung Islam Kepaon dibagi menjadi dua bagian, yaitu permukiman pada bagian timur dan permukiman pada bagian barat dengan pola permukiman yang mengikuti arah jalan dan dipisahkan oleh sebuah sungai. Sementara itu, pola permukiman di Kawasan Kampung Melayu Kota Semarang membentuk pola permukiman kolonisasi/mengelompok dengan bentuk pola permukiman secara keseluruhan menyerupai persegi panjang. Selain itu, blok permukiman yang terdapat pada bagian dalam permukiman membentuk pola yang teratur dan juga mengikuti pola jalan yang terdapat di dalam kawasan tersebut, sedangkan blok permukiman yang terdapat pada bagian timur (sepanjar koridor Jalan Layur) membentuk pola koloniasi/mengelompok yang mengikuti arah kali (sungai). Terbentuknya pola permukiman kolonisasi/mengelompok di Kampung Islam Kepaon dan Kawasan Kampung Melayu dapat disimpukan karena adanya faktor sejarah dan juga kuatnya sistem kekerabatan. Adanya fenomena pola permukiman multietnik yang digambarkan pada Kampung Islam Kepaon di Kota Denpasar dan Kawasan Kampung Melayu di Kota Semarang memperkaya konsep/teori yang berkaitan dengan permukiman multietnik (pola permukiman) dan kohesi sosial (sistem kekerabatan). Di sisi lainnya, adanya penelitian ini memperkaya empiri yang berkaitan dengan permukiman multietnik dari sisi konsep ruang permukiman etnik yang digambarkan pada pola permukiman multietnik baik di Kampung Islam Kepaon Kota Denpasar dan Kawasan Kampung Melayu Kota Semarang. 


\section{BIBLIOGRAFI}

Agustian, Endy. (2017). Nilai Nilai Lokal Sebagai Basis Perencanaan Permukiman Berkelanjutan. Plano Madani: Jurnal Perencanaan Wilayah Dan Kota, 6(2), 115127. Google Scholar

Agustian, Endy, Rachmawati, Rini, Rijanta, Raden, \& Pitoyo, Agus Joko. (2020). Characteristic of multi-ethnic settlement in Indonesia, a case study: Kampung 3-4 Ulu Laut settlement on Musi Riverbank in Palembang City. E3S Web of Conferences, 200, 3002. Google Scholar

Agustian, E., Rachmawati, R., Rijanta, R., \& Pitoyo, A. J. (2020). Multi-ethnic Settlement Concept in Denpasar City, Bali, Indonesia. Journal of Physics: Conference Series, 1655 (012132), 1-12. Google Scholar

Al-Haroun, Yousef, \& Al-Ajmi, Mohammed. (2018). Understanding socio-cultural spaces between the Hadhar and Badu houses in Kuwait. ArchNet-IJAR: International Journal of Architectural Research, 12(3), 68. Google Scholar

Ariestadi, Dian, \& Wulandari, Lisa Dwi. (2017). Architecture, space and power in historical multi-ethnic city Gresik. MATEC Web of Conferences, 101, 5027. EDP Sciences. Google Scholar

Chai, Choon Lee, Ueland, Kayla, \& Phiri, Tabitha. (2018). The use of human capital and limitations of social capital in advancing economic security among immigrant women living in central Alberta, Canada. Social Sciences, 7(11), 220. Google Scholar

Kardono, P. (2015). Pengembangan Wilayah Permukiman dalam Perspektif Geoaspasial. Jakarta: Polimedia Publishing.

Konstantinov, Vsevolod. (2017). The role of the host local population in the process of migrants' adaptation. Social Sciences, 6(3), 92. Google Scholar

Maguire, J., Grant., Louise, M., \& Joe, B. (2002). Sports World: A Sociological perspectiv. Champaign, 1L: Human Kinetics.

Markovich, N. C., Preiser, W., \& Strum, F. G. (2015). Peublo Style and Regional Achitecture. New York: Routledge. Google Scholar

Maximova, Olga Aleksandrovna, \& Belyaev, Vladimir Aleksandrovich. (2017). Generational Indigenation in a Multi-Ethnic and Multi-Religious Society (Tatarstan, Russia). Opción: Revista de Ciencias Humanas y Sociales, (84), 38-64. Google Scholar

Na'im, A., \& Syaputra, H. (2010). Kewarganegaraan, Suku Bangsa, Agama, dan Bahasa Sehari-hari Penduduk Indonesia. Jakarta: Badan Pusat Statistik. Google Scholar

Stake, Robert E. (2013). Multiple case study analysis. Guilford press. Google Scholar 
Streletsky, Vladimir N. (2017). Ethnic, confessional and cultural patterns of regionalism in the post-Soviet Russia. Hungarian Geographical Bulletin, 66(3), 219-233.

Thomas, J., \& David, B. (2016). Handbook of Landscape Archaecology. London and New York: Routledge.

Wang, Siqin, Sigler, Thomas, Corcoran, Jonathan, \& Liu, Yan. (2019). Modelling the spatial dynamics of Mainland China-born migrants in Australia. Australian Geographer, 50(2), 201-219. Google Scholar

Wesnawa, I. G. A. (2015). Geografi Permukiman. Yogyakarta:Graha Ilmu.

Woy, Valeria, Siahaan, Uras, \& Tobing, Rumiati R. (2018). Adaptasi Arsitektur Hunian Etnik Campuran Di Sulawesi Utara. Jurnal Penelitian Dan Karya Ilmiah Arsitektur Usakti, 16(1), 14-24. Google Scholar

Yin, Robert K. (2014). Case study research: design and methods. Fifth edit. United Stated of America. Google Scholar

Zain, Zairin, \& Alam, Rinada Shafa. (2017). Identifikasi Pola Struktur Rumah Tinggal, Studi Kasus: Arsitektur Tradisional Melayu Di Kota Pontianak. Langkau Betang: Jurnal Arsitektur, 4(1), 44-66. Google Scholar

Zhang, Bo, Druijven, Peter, \& Strijker, Dirk. (2019). Hui family migration in Northwest China: patterns, experiences and social capital. Ethnic and Racial Studies, 42(12), 2008-2026. Google Scholar

\section{Copyright holder:}

Endy Agustian, Rini Rachmawati, R Rijanta dan Agus Joko Pitoyo (2021)

First publication right:

Journal Syntax Literate

This article is licensed under: 